\title{
Using of Potassium Silicate to Alleviate Drought Stress Effect on Peanut as Grown in Sandy Soil
}

\author{
Gomaa, M. A. ${ }^{1}$, I. F. I. Rehab ${ }^{1}$, Essam. E. Kandil ${ }^{1}$, A. M. Ali ${ }^{2}$ and W. B. G. \\ Abd elhafez ${ }^{1}$
}

1.Plant Production Dept. Faculty of Agriculture (Saba Basha) Alexandria University.

2.Dept.of Soil Fertility and Microbiology, Desert Research Center, Cairo, Egypt.

DOI: $10.21608 /$ jalexu.2021.179977

Article Information

Received:June $8^{\text {th }} 2021$

Revised: June $9^{\text {th }} 2021$

Accepted:June $16^{\text {th }} 2021$

Published: June $26^{\text {th }} 2021$
ABSTRACT Two field Experiments were conducted at Abd El-Maneim Ryad, South Tahrir, El- Beheira Governorate, Egypt, during the summer growing seasons of 2017 and 2018 to study the role of foliar application of potassium silicate for alleviating drought stress effect on peanut grown in sandy soil. This experiment carried out in a split plot design with three replicates where the drought stress treatments (irrigation after depletion of $40 \%, 55 \%, 70 \%$ and $85 \%$ Available soil water were occupied main plot, while potassium silicate concentration (control, 500, 1000 and $1500 \mathrm{mg} / \mathrm{l}$ silicate) was allocated in sub main plot.

Results revealed that irrigation after depletion of $55 \%$ available soil water recorded the highest mean values of yield and yield components i.e. (100-pods weight, no. of pods/plant, pods yield/fed, biological yield/fed and straw yield/fed during both seasons, while, the irrigation after depletion of $40 \%$ available soil water recorded the highest mean values of harvest index percentage during both seasons).

Foliar application of potassium silicate at $1500 \mathrm{mg} / \mathrm{l}$ silicate recorded the maximum 100pods weight, no. of pods/plant, pods yield/fed, biological yield/fed and straw yield/fed, while, control treatment recorded the highest mean values of harvest index percentage during both seasons. Chemical compositions i.e. (oil percentage and oil yield/fed) recorded the best values with irrigation after depletion of $40 \%$ available soil water, while, proline content recorded the highest mean values at irrigation after $85 \%$ depletion of available water; in addition, potassium silicate at $1500 \mathrm{mg} / \mathrm{l}$ silicate recorded the highest percentages of oil and oil yield/fed, while, proline content recorded the best values with control treatment, during both seasons. Water use efficiency recorded the highest mean value with irrigation after depletion of $85 \%$ available soil water during both seasons; with regard, potassium silicate at $1500 \mathrm{mg} / \mathrm{l}$ silicate gave the highest mean values of water use efficiency as compared with control treatment which recorded the lowest mean values of WUE during both seasons.

Keywords: Peanut, drought stress, potassium silicate, yield and yield components.

\section{INTRODUCTION}

Groundnut or peanut (Arachis hypogaea L.) is considered to be one of the most important edible legume crops in Egypt, due to its seeds has high nutritive value for human and the produced cake as well as the green leafy hay for livestock (Abdalla et al., 2009). Peanut is one of the most important cash crops, besides food crops and oil seed crops, in the world. However, most of the world's peanut production is grown mostly under rain-fed conditions, where unpredicted and inadequate rainfall or drought seriously affects peanut production (Icrisat, 2011). Peanut is the world's $4^{\text {th }}$ most essential edible oil crop and $3^{\text {rd }}$ most vital source of vegetable protein (CGIAR, 2005). Peanut is a vital legume crop grown in tropical and sub-tropical semi-arid regions of the world; the yield level is severely affected by deficiency of soil moisture. Peanut is a main seed legume in Egypt as compared with other oil crops (Arruda et al., 2015).

Drought is the most limiting factor, resulting in low yields in many parts of the world (Songsri et al., 2008). Drought during the pod filling phase of peanut is common and causes the greatest reduction in peanut pod yield (Ravindra et al., 1990). Also, Girdthai et al. (2010) stated that drought reduced pod yield up to $35 \%$ and biomass by $21 \%$.Water deficit stress is one of the main environmental restraints limiting agricultural productivity and acts avital role in the distribution of plant species across different types of environments (Ashraf, 2010). Drought stress has been the major environmental factor responsible to yield losses in numerous crops worldwide. The losses are highly flexible reliant on timing, intensity, and period coupled with other location-specific environmental stress factors such as temperature and salinity (Kambiranda et al., 2012). Drought not only results in yield loss, but also is the chief reason for decrease innutritional quality of seed (Amir et al., 2005) and rises in aflatoxin contamination (Girdthai et al., 2010).

Silicon ( $\mathrm{Si}$ ) is one of the abundant elements in the lithosphere and it is the most abundant element in soil next to oxygen and comprises 28 percent of its weight and $3-7$ percent in soil solution (Epstein, 1999). Si is most 
commonly found in soils in the form of solution as silicic acid and plants take up directly as silicic acid (Ma, et al., 2001). Application of silicon increased the shoot silicon concentration and dry matter production (Prakash, et al., 2011). Silicon can be enhanced plant resistance to manyabiotic stresses: salinity, drought, metal toxicity and ultra violet radiation (Balakhnina and Borkowska, 2013). Silicon spraying improved growth and physiological indices hence could increase the ability of plants to resistance water stress. Silicon application reduces transpiration leads to water stress tolerance (Asgharipour and Mosapour, 2016). The role of silicon in plant biology is to decrease various stresses such asbiotic and abiotic stresses. Si helps to protect crops from insect attack, disease and environmental stress. In organic farming system, the addition of silicon sources to crops may increase the yield and decreasing the use of chemical fertilizers, pesticides and fungicides (Patil, et al., 2017). Si can improve growth, biomass and yield of wide range of crops including monocotyledonous crops that have the capability to collect high amounts of $\mathrm{Si}$ in their organs (Shedeed,2018).

Foliar application of $\mathrm{K}$ - silicate has many benefits in enhancing leaf erectness and photosynthesis efficiency also decreasing capability to lodging in herbal crops (Ahmad et al., 2013). In addition, Si offers benefits in numerous agricultural applications e.g. increases growth and yield, improves strength, minimize climate stress and provides impedance to mineral stress. On this way Kandil Table (1). The initial physical and chemical properties et al. (2019) found that K- silicate increased yield, yield components and quality of soybean under environmental stress.Also, Gomaa et al. (2020) and Gomaa et al. (2021b) revealed that foliar application of $\mathrm{K}$-silicate three times resulted in the highest growth, yield and grain characters can increase WUE of maize. On the other hand, under water-deficit stress, irrigation every fifteen days combined with application of K-silicate spraying in three times recorded the highest values of growth and grain yield and its components. Also, El-Naggar et al. (2020) indicated that using $\mathrm{Si}$ in Nanoparticles increased yield and its components of maize. Gomaa et al. (2021a) showed that application of Si increased yield and its components of maize.

The overall objective of the present research was to study the role of foliar application of potassium silicate for alleviating drought stress effect on peanut grown in sandy soil.

\section{MATERIALS AND METHODS}

Two field Experiments were conducted at Abd El-Maneim Ryad, South Tahrir, Beheira, Governorate, Egypt, in the summer growing seasons of 2017 and 2018 to study the alleviating drought stress effect on peanut grown in sandy soil using foliar application of potassium silicate.

The preceding crop was Potato (Solanum tuberosum L.) in the two seasons. The physical and chemical properties of experimental soil are presented in Table (1) according to the method described by Page et al. (1982).

\begin{tabular}{|c|c|c|}
\hline Physical properties & 2017 & 2018 \\
\hline Sand $(\%)$ & 95.52 & 98.58 \\
\hline Silt (\%) & ---- & ---- \\
\hline Clay (\%) & 4.48 & 1.42 \\
\hline Textural class & Sand & Sand \\
\hline \multicolumn{3}{|l|}{ Chemical properties } \\
\hline $\mathrm{pH}$ & 8.7 & 7.58 \\
\hline $\mathrm{EC}(\mathrm{dS} / \mathrm{m})$ & 0.39 & 0.27 \\
\hline O. M (\%) & 0.31 & 0.32 \\
\hline $\mathrm{Ca} \mathrm{CO}_{3}(\%)$ & 0.31 & 0.31 \\
\hline \multicolumn{3}{|c|}{ Soluble Cations (meq /L) } \\
\hline $\mathrm{Ca}^{+2}$ & 1.50 & 1.96 \\
\hline $\mathrm{Mg}^{+2}$ & 3.50 & 3.75 \\
\hline $\mathrm{Na}^{+1}$ & 1.85 & 1.83 \\
\hline $\mathrm{K}^{+1}$ & 0.64 & 0.66 \\
\hline
\end{tabular}

Soluble Anions (meq /L)

$\mathrm{HCO}_{3}{ }^{-1}$
$\mathrm{Cl}^{-1}$
$\mathrm{SO}_{4}^{-2}$

Available nutrients (mg/kg soil)

$\mathrm{N}$

$\mathrm{P}$

$\mathrm{K}$
3. 20

2. 40

3. 27

1. 24

2. 31

1. 26

123.13 


\section{Experimental layout}

The experiments were carried out in a split plot design with three replicates, where the irrigation treatment i.e. (irrigation after depletion of $40 \%, 55 \%, 70 \%$ and $85 \%$ available soil water) was applied after ten days from planting were arranged in the main plots, then the four potassium silicate (control=spray tap water, 500, 1000 and $1500 \mathrm{mg} / \mathrm{l}$ silicate) as applied after 35, 45, 55 and 65 days from planting and were allocated in the subplots.

Peanut (Arachis hypogaea L.) variety Giza 6 were planted on $20^{\text {th }}$ April and harvested on $18^{\text {th }}$ of August in the two seasons 2017 and 2018.

Table (2). Field capacity (FC), permanent wilting point (PWP), available soil water (ASW), and bulk density (BD) of the experimental soil.

\begin{tabular}{|c|c|c|c|c|c|c|c|c|}
\hline \multirow{3}{*}{$\begin{array}{l}\text { Depth of } \\
\text { Soil } \\
(\mathrm{cm})\end{array}$} & \multicolumn{8}{|c|}{ Season } \\
\hline & \multicolumn{4}{|c|}{2017} & \multicolumn{4}{|l|}{2018} \\
\hline & $\begin{array}{l}\mathrm{FC} \\
(\%)\end{array}$ & $\begin{array}{l}\text { PWP } \\
(\%)\end{array}$ & $\begin{array}{l}\text { ASW } \\
(\%)\end{array}$ & $\begin{array}{l}\mathrm{BD} \\
\mathrm{g} / \mathrm{cm}^{3}\end{array}$ & $\begin{array}{l}\mathrm{FC} \\
(\%)\end{array}$ & $\begin{array}{l}\text { PWP } \\
(\%)\end{array}$ & $\begin{array}{l}\text { ASW } \\
(\%)\end{array}$ & $\begin{array}{l}\mathrm{BD} \\
\mathrm{g} / \mathrm{cm}^{3}\end{array}$ \\
\hline $0-30$ & 8.6 & 4.6 & 4.0 & 1.63 & 8.7 & 4.7 & 4.0 & 1.44 \\
\hline
\end{tabular}

\section{Determination of available water}

$\mathrm{AW}(\mathrm{mm})=\left(\theta_{\mathrm{fc}}-\theta_{\mathrm{pwp}}\right) \mathrm{Dr}$

$\operatorname{AW}(\%)=\left(\theta_{\mathrm{fc}}-\theta_{\mathrm{pwp}}\right)$

Where:

$\mathrm{AW}=$ depth of water available

$\theta_{\mathrm{fc}}=$ volumetric field capacity

$\theta_{\mathrm{pwp}}=$ volumetric permanent wilting point

$\mathrm{Dr}=$ depth of root zone

\section{Determination of depletion (\%) \\ Depletion of $40 \%$ available soil water $=0.40 \times \mathrm{AW}(\%)$ \\ Depletion of $55 \%$ available soil water $=0.55 \times \mathrm{AW}(\%)$ \\ Depletion of $70 \%$ available soil water $=0.70 \times \mathrm{AW}(\%)$ \\ Depletion of $85 \%$ available soil water $=0.85 \times \mathrm{AW}(\%)$}

\section{Soil moisture content}

Soil moisture (\%) was measured using the following equation:

Soil moisture $(\%)=\frac{\text { Weight before drying }- \text { weight after drying }}{\text { Weight after drying }} \times 100$

To convert into volumetric moisture content, the dry weight fraction is multiplied by the bulk density, $\gamma$

\section{Irrigation treatments}

Irrigation after depletion of $40 \%$ available soil water

$=$ field capacity - depletion of $40 \%$ available soil water

Irrigation after depletion of $55 \%$ available soil water

$=$ field capacity - depletion of $55 \%$ available soil water

Irrigation after depletion of $70 \%$ available soil water

= field capacity - depletion of $70 \%$ available soil water

Irrigation after depletion of $85 \%$ available soil water

$=$ field capacity - depletion of $85 \%$ available soil water

\section{Fertilizer application}

Before sowing were applied $300 \mathrm{~kg} / \mathrm{fed}$ super phosphate calcium and $100 \mathrm{~kg}$ sulphur/fed during soil preparation. After sowing all experimental units were received fertilizer as 40 and $25 \mathrm{~kg} /$ fed of $\mathrm{N}$ and $\mathrm{K}$, respectively. Sources of these fertilizers were ammonium nitrate $(33.5 \% \mathrm{~N})$ and potassium sulphate $\left(50 \% \mathrm{~K}_{2} \mathrm{O}\right)$, while, $\mathrm{N}$ fertilizer was added in four equal doses and $\mathrm{K}$ fertilizer were added in two equal doses during vegetative growth. The experimental units were hand hoed three times for controlling. Other agricultural practices were done as recommended by the Ministry of Agriculture and Land Reclamation.

\section{Studied characters}

Yield and yield components such as 100-pods weight (g), no. of pods/plant, pods yield ( $\mathrm{kg} / \mathrm{fed})$, straw yield $(\mathrm{kg} / \mathrm{fed})$, biological yield $(\mathrm{kg} / \mathrm{fed})$, and harvest index $(\%)$ as well as chemical composition such as proline $(\mathrm{mg} / \mathrm{g})$ and oil $(\%)$ in addition to water use efficiency $\left(\mathrm{Kg} / \mathrm{m}^{3}\right)$ were studied.

\subsection{Statistical analysis}

The obtained data were subjected to the proper method of statistical analysis of variance as described by Gomez and Gomez (1984). The treatment means 
were compared using the least significant differences (L.S.D.) at 0.05 level of probability by SAS (Statistical Analysis System) version 9.1 (2002).

\section{RESULTS AND DISCUSSION}

\section{A) Yield and yield components}

Result tabulated in Table (3) showed irrigation after depletion of $55 \%$ available soil water recorded the heaviest 100 pods weight (209.36 and $198.80 \mathrm{~g}$ ), maximum number of pods/plant (43.25 and $39.81)$ and pods yield (2910.74 and $2374.46 \mathrm{~kg} / \mathrm{fed})$ in two seasons, respectively, as compared to irrigation after depletion of $40 \%$ available soil water which recorded the lowest 100 pods weight (162.70 and $154.56 \mathrm{~g})$, minimum number of pods/plant (28.66 and $26.45)$ and pods yield/fed (2514.17 and $2114.01 \mathrm{~kg}$ ), during both seasons, respectively. Number of pods per plant was the most vulnerable item damaged by drought stress (Pandey et al., 1984). The effect of drought stress on the yield of three bean cultivars showed that stress at flowering stage reduced the number of pods per plant and seeds per pod in all three varieties (Fienebaum $\boldsymbol{e t}$ al., 1991). The number of pods/plant reduced due to drought stress (Seyed et al., 2011). Also, Gomaa et al. (2020) and Gomaa et al. (2021b) reported the similar results, who found that water stress reduced growth and yield characters of maize.

The yield advantages due to moderate water deficit during the pre-flowering phase are associated with greater pod synchrony after the release of water stress, resulting in production of more mature pods (Nageswara et al., 1988). When stress is released, the plant try to set more fruiting sites with the existing assimilates as the vegetative site demanding assimilate supply are reduced. To improve the conventional irrigation management practices to enhance yield and water use efficiency in groundnut during summer seasons a field experiment was conducted by Nautiyal et al. (2002) where dry matter partitioning among various plant parts, and leaf area index (LAI) varied significantly under water deficit and more dry matter accumulated in petiole and stem under stress. The pod development are progressively inhibited by drought due to insufficient soil moisture and lack of assimilate
(Reddy et al., 2003). Girdthai et al. (2010) found that peanut pod yield is decreased when subjected to drought stress due to reduction in the photosynthetic rate and disrupts the carbohydrate metabolism (Farooq et al., 2009). Moreover, most of stressed peanut genotypes had lower pod growth rate than peanut having Field capacity (FC) treatment, indicating that the assimilate portion may enhance to support the economic part. Prabawo et al. (1990) reported that rewatering after pod filling stages increased pod yields of Spanish type peanuts. Yield loss caused by moisture stress depends on genotype, plant developmental stage, severity and duration of water shortage (Korte $\boldsymbol{e t}$ al., 1993).Under drought conditions, the peanut agronomic characteristics and grain yield of all cultivars decreased and a significant reaction of the genotypes was observed (Vorasoot et al., 2003).

In this respect, increasing the concentration of potassium silicate foliar application increased 100 pods weight, number of pods/plant and pods yield/fed,whereas, foliar application of potassium silicate at $1500 \mathrm{mg} / \mathrm{l}$ silicate recorded the maximum 100 pods weight $(214.75$ and $204.01 \mathrm{~g})$, number of pods/plant (42.17 and 38.79)and pods yield/fed (2965.97 and $2610.04 \mathrm{~kg}$ ), as compared to control treatment which recorded the lowest mean values of 100-pods weight (156.55 and $147.42 \mathrm{~g}$ ), number of pods/plant (30.74 and 28.35) and pods yield/ fed (2420.99 and $1902.72 \mathrm{~kg}$ ) during both seasons, respectively. These results are agreement with those results reported by Gomaa et al. (2020) and Gomaa et al. (2021a)

The interaction between irrigation treatments (A) and potassium silicate concentration (B) was significant on 100 pods weight, number of pods/plant and pods yield/fed during both seasons. The greatest values of these traits were recorded when peanut crop were irrigated after depletion of $55 \%$ available soil water under foliar application of potassium silicate at $1500 \mathrm{mg} / \mathrm{l}$ silicate, whereas the lowest values resulted from irrigation after depletion of $40 \%$ available soil water under tap water spray (control) during both seasons. 
Table (3). Effect of irrigation levels (A), potassium silicate (B) and their interaction (A*B) on 100pods weight, No. of pods/plant and of Pods yield peanut during 2017 and 2018 seasons

\begin{tabular}{|c|c|c|c|c|c|c|c|}
\hline \multirow{2}{*}{\multicolumn{2}{|c|}{ Treatments }} & \multicolumn{2}{|c|}{$\begin{array}{l}\text { 100-pods weight } \\
(\mathrm{g})\end{array}$} & \multicolumn{2}{|c|}{$\begin{array}{c}\text { No. of pods/ } \\
\text { plant }\end{array}$} & \multicolumn{2}{|c|}{$\begin{array}{c}\text { Pods yield } \\
(\mathrm{kg} / \mathrm{fed})\end{array}$} \\
\hline & & 2017 & 2018 & 2017 & 2018 & 2017 & 2018 \\
\hline \multicolumn{8}{|c|}{ A) Irrigation levels } \\
\hline \multicolumn{2}{|l|}{$85 \%$} & $172.10 \mathrm{c}$ & $163.49 \mathrm{c}$ & $34.10 \mathrm{c}$ & $31.36 \mathrm{c}$ & $2589.99 \mathrm{c}$ & $2188.61 \mathrm{c}$ \\
\hline \multicolumn{2}{|l|}{$70 \%$} & $194.37 b$ & $183.35 b$ & $38.98 b$ & $35.86 \mathrm{~b}$ & $2734.12 b$ & $2298.87 b$ \\
\hline \multicolumn{2}{|l|}{$55 \%$} & $209.36 a$ & $198.80 \mathrm{a}$ & $43.25 \mathrm{a}$ & $39.81 \mathrm{a}$ & $2910.74 a$ & $2374.46 a$ \\
\hline \multicolumn{2}{|l|}{$40 \%$} & $162.70 \mathrm{~d}$ & $154.56 \mathrm{~d}$ & $28.66 \mathrm{~d}$ & $26.45 d$ & $2514.17 \mathrm{~d}$ & $2114.01 d$ \\
\hline \multicolumn{2}{|l|}{$\mathbf{L S D}_{(0.05)}$} & 6.11 & 5.56 & 1.82 & 1.25 & $\mathbf{5 7 . 5 8}$ & 46.07 \\
\hline \multicolumn{8}{|c|}{ B) Potassium silicate } \\
\hline \multicolumn{2}{|c|}{ Control } & $156.55 \mathrm{~d}$ & $147.42 \mathrm{~d}$ & $30.74 d$ & $28.35 d$ & $2420.99 d$ & $1902.72 d$ \\
\hline \multicolumn{2}{|l|}{$500 \mathrm{mg} / \mathrm{l}$} & $173.95 \mathrm{c}$ & $165.25 \mathrm{c}$ & $34.13 c$ & $31.42 \mathrm{c}$ & $2588.01 \mathrm{c}$ & $2114.14 \mathrm{c}$ \\
\hline \multicolumn{2}{|c|}{$1000 \mathrm{mg} / \mathrm{l}$} & $193.28 b$ & $183.61 b$ & $37.95 b$ & $34.91 \mathrm{~b}$ & $2774.05 b$ & $2349.04 b$ \\
\hline \multicolumn{2}{|c|}{$1500 \mathrm{mg} / \mathrm{l}$} & $214.75 \mathrm{a}$ & $204.01 \mathrm{a}$ & $42.17 \mathrm{a}$ & $38.79 \mathrm{a}$ & $2965.97 \mathrm{a}$ & $2610.04 \mathrm{a}$ \\
\hline \multicolumn{2}{|l|}{$\mathbf{L S D}_{(0.05)}$} & 0.40 & 1.93 & 0.15 & 0.21 & 10.91 & 2.44 \\
\hline \multicolumn{2}{|c|}{ The interaction $(A * B)$} & $*$ & $*$ & $*$ & $*$ & $*$ & $*$ \\
\hline \multicolumn{2}{|c|}{$\begin{array}{cc}\begin{array}{c}\text { Irrigation } \\
\text { levels }\end{array} & \begin{array}{c}\text { Potassium } \\
\text { silicate } \\
(\mathrm{mg} / \mathrm{l})\end{array} \\
\end{array}$} & & & & & & \\
\hline \multirow{4}{*}{$85 \%$} & Control & 145.93 & 138.63 & 28.91 & 26.54 & 2301.80 & 1855.76 \\
\hline & 500 & 162.14 & 154.03 & 32.13 & 29.56 & 2475.01 & 2061.96 \\
\hline & 1000 & 180.16 & 171.15 & 35.70 & 32.84 & 2690.34 & 2291.07 \\
\hline & 1500 & 200.17 & 190.16 & 39.67 & 36.49 & 2892.79 & 2545.63 \\
\hline \multirow{4}{*}{$70 \%$} & Control & 164.81 & 151.36 & 33.05 & 30.40 & 2444.09 & 1949.26 \\
\hline & 500 & 183.12 & 173.97 & 36.72 & 33.78 & 2628.06 & 2165.84 \\
\hline & 1000 & 203.47 & 193.30 & 40.80 & 37.54 & 2825.77 & 2406.49 \\
\hline & 1500 & 226.08 & 214.77 & 45.33 & 41.70 & 3038.56 & 2673.88 \\
\hline \multirow{4}{*}{$55 \%$} & Control & 177.52 & 168.65 & 36.69 & 33.75 & 2690.66 & 2013.35 \\
\hline & 500 & 197.25 & 187.38 & 40.69 & 37.51 & 2832.42 & 2237.06 \\
\hline & 1000 & 219.16 & 208.21 & 45.30 & 41.68 & 2981.46 & 2485.62 \\
\hline & 1500 & 243.52 & 231.34 & 50.33 & 46.31 & 3138.41 & 2761.80 \\
\hline \multirow{4}{*}{$40 \%$} & Control & 137.96 & 131.06 & 24.30 & 22.69 & 2247.42 & 1792.51 \\
\hline & 500 & 153.28 & 145.62 & 27.00 & 24.84 & 2416.54 & 1991.68 \\
\hline & 1000 & 170.32 & 161.80 & 30.00 & 27.60 & 2598.62 & 2212.98 \\
\hline & 1500 & 189.24 & 179.77 & 33.33 & 30.67 & 2794.10 & 2458.86 \\
\hline \multicolumn{2}{|l|}{$\mathbf{L S D}_{(0.05)}$} & 0.46 & 2.23 & 0.18 & 0.24 & 12.60 & 2.81 \\
\hline
\end{tabular}

- Irrigation level: irrigation after depletion of $40 \%, 55 \%, 70 \%$ and $85 \%$ available soil water.

Means followed by the same letter within each column are not significant different at 0.05 level of probability.

* Denotes significant at 0.05 level of probability.

The results in Table (4) illustrated that irrigation after depletion of $55 \%$ available soil water recorded the highest straw yield/fed (2598.52 and $2858.34 \mathrm{~kg}$ ) and biological yield/fed (5509.26 and $5232.80 \mathrm{~kg}$ ) during the two seasons, respectively, as compared to irrigation after depletion of $40 \%$ available soil water which recorded the minimum straw yield/ fed (1330.38 and $1463.33 \mathrm{~kg}$ ) and biological yield/fed (3844.56 and $3577.34 \mathrm{~kg}$ ), while, irrigation after depletion of $40 \%$ available soil water recorded the highest percentage of harvest index (48.50 and 49.05 $\%$ ), respectively, as compared to irrigation after depletion of $55 \%$ available soil water which recorded the minimum harvest index (40.37 and 40.70\%), during both seasons, respectively.
Toprope et al. (2004) reported that Harvest index (HI) was the critical measure of water use efficiency under water deficit stress conditions. Greater HI was observed at pegging and pod development stage under drought conditions. Yield loss caused by moisture stress depends on genotype, plant developmental stage, severity and duration of water shortage (Korte et al., 1993).Under drought conditions, the peanut agronomic characteristics and grain yield of all cultivars decreased, and a significant reaction of the genotypes was observed (Vorasoot et al., 2003).

Also, data in Table (4) indicated that all potassium silicate concentration significantly increased straw yield/fed and biological yield/fed, generally, potassium silicate concentration at $1500 \mathrm{mg} / \mathrm{l}$ silicate recorded the highest straw yield/fed (2230.47 and 
$2453.51 \mathrm{~kg}$ ) and biological yield/ fed (5196.44 and $5063.55 \mathrm{~kg})$, while, potassium silicate at control recorded the highest harvest index percentage (44.77 and $46.85 \%$ ), respectively, as compared with all treatments during both seasons.

The interaction between irrigation treatments and potassium silicate concentration was highly significant for straw yield/fed, biological yield and not significant for harvest index percentage during both seasons. The maximum values of the straw yield/fed and biological yield/fed were recorded when peanut crop were irrigated after depletion of $55 \%$ available soil water under foliar application of potassium silicate at 1500 $\mathrm{mg} / \mathrm{l}$ silicate in both seasons, whereas the lowest ones were given with irrigation after depletion of $40 \%$ available soil water under tap water spray (control) in both cropping seasons. Harvest index (\%) under irrigation after depletion of $40 \%$ available soil water and tap water spray (control) recorded the maximum values, while, the minimum values recorded under irrigation after depletion of $55 \%$ available soil water and foliar application of potassium silicate at $1500 \mathrm{mg} / \mathrm{l}$ silicate during both cropping seasons.

Table (4). Effect of irrigation levels (A) potassium silicate (B) and their interaction (A * B) for straw, biological yield and harvest index during 2017 and 2018 seasons.

\begin{tabular}{|c|c|c|c|c|c|c|c|}
\hline \multirow{2}{*}{\multicolumn{2}{|c|}{ Treatments }} & \multicolumn{2}{|c|}{$\begin{array}{l}\text { Straw yield } \\
\text { (kg/ fed) }\end{array}$} & \multicolumn{2}{|c|}{$\begin{array}{l}\text { Biological yield } \\
\text { (kg/ fed) }\end{array}$} & \multicolumn{2}{|c|}{$\begin{array}{c}\text { Harvest index } \\
(\%)\end{array}$} \\
\hline & & 2017 & 2018 & 2017 & 2018 & 2017 & 2018 \\
\hline \multicolumn{8}{|c|}{ A) Irrigation levels } \\
\hline \multicolumn{2}{|c|}{$85 \%$} & $1662.98 \mathrm{c}$ & $1829.33 c$ & $4252.97 \mathrm{c}$ & $4017.93 \mathrm{c}$ & $46.21 \mathrm{~b}$ & $46.86 b$ \\
\hline \multicolumn{2}{|l|}{$70 \%$} & $2078.71 b$ & $2286.61 b$ & $4812.83 b$ & $4585.48 b$ & $44.22 \mathrm{c}$ & $44.17 \mathrm{c}$ \\
\hline \multicolumn{2}{|l|}{$55 \%$} & $2598.52 \mathrm{a}$ & $2858.34 \mathrm{a}$ & $5509.26 \mathrm{a}$ & $5232.80 \mathrm{a}$ & $40.37 d$ & $40.70 d$ \\
\hline \multicolumn{2}{|l|}{$40 \%$} & $1330.38 \mathrm{~d}$ & $1463.33 \mathrm{~d}$ & $3844.56 \mathrm{~d}$ & $3577.34 \mathrm{~d}$ & $48.50 \mathrm{a}$ & $49.05 \mathrm{a}$ \\
\hline \multicolumn{2}{|l|}{$\mathbf{L S D}_{(0.05)}$} & 46.42 & 51.01 & 76.88 & 67.99 & 0.52 & 0.50 \\
\hline \multicolumn{8}{|c|}{ B) Potassium silicate } \\
\hline \multicolumn{2}{|c|}{ Control } & $1626.04 d$ & $1788.61 d$ & $4047.01 d$ & $3691.33 d$ & $44.77 \mathrm{a}$ & $46.85 \mathrm{a}$ \\
\hline \multicolumn{2}{|c|}{$500 \mathrm{mg} / 1$} & $1806.68 \mathrm{c}$ & $1987.34 c$ & $4394.69 c$ & $4101.47 \mathrm{c}$ & $43.90 \mathrm{~b}$ & $45.73 b$ \\
\hline \multicolumn{2}{|c|}{$1000 \mathrm{mg} / \mathrm{l}$} & $2007.42 b$ & $2208.16 b$ & $4781.47 b$ & $4557.20 \mathrm{~b}$ & $43.02 \mathrm{c}$ & $44.50 \mathrm{c}$ \\
\hline \multicolumn{2}{|c|}{1500 mg/l } & $2230.47 \mathrm{a}$ & $2453.51 \mathrm{a}$ & $5196.44 a$ & $5063.55 \mathrm{a}$ & $42.16 \mathrm{~d}$ & $42.98 \mathrm{~d}$ \\
\hline \multicolumn{2}{|c|}{$\mathbf{L S D}_{(0.05)}$} & 9.62 & 10.58 & 16.55 & 10.05 & 0.1 & 0.11 \\
\hline \multicolumn{2}{|c|}{$\begin{array}{l}\text { The interaction } \\
(\mathbf{A} * \mathbf{B})\end{array}$} & $* *$ & $* *$ & $* *$ & $* *$ & ns & ns \\
\hline $\begin{array}{c}\text { Irrigation } \\
\text { Levels }\end{array}$ & $\begin{array}{c}\text { Potassium } \\
\text { silicate } \\
(\mathrm{mg} / \mathrm{l})\end{array}$ & & & & & & \\
\hline \multirow{4}{*}{$85 \%$} & Control & 1410.08 & 1551.13 & 3375.50 & 3033.30 & 46.19 & 48.29 \\
\hline & 500 & 1566.75 & 1723.47 & 3669.94 & 3337.34 & 45.26 & 47.77 \\
\hline & 1000 & 1740.84 & 1914.97 & 3991.29 & 3744.82 & 44.35 & 45.94 \\
\hline & 1500 & 1934.26 & 2127.74 & 4341.51 & 4160.91 & 43.46 & 44.46 \\
\hline \multirow{4}{*}{$70 \%$} & Control & 1762.58 & 1938.86 & 4894.00 & 4437.00 & 44.90 & 46.47 \\
\hline & 500 & 1958.42 & 2154.30 & 5280.57 & 4929.99 & 44.01 & 44.98 \\
\hline & 1000 & 2176.02 & 2393.66 & 5701.63 & 5477.77 & 43.13 & 43.52 \\
\hline & 1500 & 2417.80 & 2659.63 & 6160.83 & 6086.42 & 42.27 & 42.12 \\
\hline \multirow{4}{*}{$55 \%$} & Control & 2203.34 & 2423.64 & 4206.66 & 3888.12 & 38.65 & 40.49 \\
\hline & 500 & 2448.15 & 2692.93 & 4586.49 & 4320.13 & 37.90 & 39.19 \\
\hline & 1000 & 2720.17 & 2992.15 & 5001.79 & 4800.15 & 37.14 & 38.61 \\
\hline & 1500 & 3022.41 & 3324.61 & 5456.37 & 5333.50 & 36.40 & 37.10 \\
\hline \multirow{4}{*}{$40 \%$} & Control & 1128.06 & 1240.79 & 3711.88 & 3406.89 & 51.75 & 54.71 \\
\hline & 500 & 1253.40 & 1378.66 & 4041.76 & 3785.43 & 50.72 & 53.62 \\
\hline & 1000 & 1392.67 & 1531.84 & 4431.18 & 4206.04 & 49.98 & 52.35 \\
\hline & 1500 & 1547.41 & 1702.05 & 4827.06 & 4673.37 & 48.15 & 50.67 \\
\hline \multicolumn{2}{|l|}{$\mathbf{L S D}_{(0.05)}$} & 11.10 & 12.22 & 29.63 & 22.05 & 0.12 & 0.10 \\
\hline
\end{tabular}

- $\quad$ Irrigation level: irrigation after depletion of $40 \%, 55 \%, 70 \%$ and $85 \%$ available soil water.

Means followed by the same letter within each column are not significant different at 0.05 level of probability.

** Denotes significant at 0.01 level of probability.

$n s$, Denotes not significant. 


\section{B ) Chemical composition}

The perusal of results in Table (5) indicated that irrigation after depletion of $85 \%$ available soil water recorded the highest proline content (236.08 and $219.55 \mathrm{mg} / \mathrm{g}$ ) in two seasons, respectively, as compared to irrigation after depletion of $40 \%$ available soil water which recorded the minimum proline content (187.19 and $174.09 \mathrm{mg} / \mathrm{g}$ ), during both seasons, respectively. The proline content enhances the drought stress progressed and reached a peak as obtained after 10 days stress, and then decreased under severe water stress as observed after 15 days of stress (Anjum et al., 2011). Proline can act as a signaling molecule to modulate mitochondrial functions, influence cell proliferation or cell death and trigger specific gene expression, which can be essential for plant recovery from stress (Szabados and Savoure, 2010). Accumulation of proline under stress in many plants has been related with stress tolerance, and its concentration has been revealed to be generally higher in stress-tolerant than in stress-sensitive plants (Demiral and Turkan, 2005).

In another side, increasing potassium silicate concentration decreased proline content, during both seasons. However, potassium silicate at 1500 $\mathrm{mg} / \mathrm{lsilicate}$ gave the lowest mean values of proline content (181.18and $168.96 \mathrm{mg} / \mathrm{g}$ ), as compared to control treatment which recorded the highest mean values of proline content (249.22 and $231.77 \mathrm{mg} / \mathrm{g}$ ), during both seasons, respectively. These findings may be related to the synergistic effect of the two studied factors on the different biochemical pathways in the plant cell. Silicon moderately offset the negative effects of drought stress by accumulation of proline and soluble protein content, thereby conferring stress tolerance (Sapre and Vakharia, 2016). In contrast, Crusciol et al. (2009) and Pilon et al. (2014) stated that proline (\%) in leaves increased under water-deficit stress and higher silicon availability, which shows that silicon may be helpwith plant osmotic adjustment. Mauad et al. (2016) indicates that under water stress conditions, silicon application the proline content in the vegetative and reproductive phases of rice plants, which could be an indicator of stress tolerance.

The interaction between irrigation treatments and potassium silicate concentration was highly significant on proline content during both seasons. Irrigation after depletion of $85 \%$ available soil water recorded the highest proline content under the foliar spraying of tap water.

Results resented in Table (5) showed that irrigation after depletion of $40 \%$ available soil water recorded the highest oil percentage (45.31 and 42.14 $\%$ ), as compared to irrigation after depletion of $85 \%$ available soil water which recorded the lowest oil percentage (34.36 and $31.95 \%$ ), during both seasons, respectively.

With regards to the effect of foliar application of different concentrations of potassium silicate increased oil percentage, during 2017 and 2018 seasons. Whereas, foliar application of potassium silicate at $1500 \mathrm{mg} / \mathrm{l}$ silicate recorded the best content of oil percentage (45.51 and $42.32 \%$ ), followed by potassium silicate at $1000 \mathrm{mg} / \mathrm{l}$ silicate (40.95 and $38.09 \%)$, as compared to control treatment which recorded the lowest mean values of oil percentage (33.17 and $30.85 \%)$, during both seasons, respectively.

The interaction between irrigation treatments and potassium silicate concentration was highly significant on oil percentage during both seasons. Oil content recorded the best results under irrigation after depletion of $40 \%$ available soil water with foliar spraying of potassium silicate at $1500 \mathrm{mg} / \mathrm{l}$ silicate in both seasons.

\section{C) Water use efficiency}

Results in Table (6) showed that increasing drought levels increased water use efficiency during both seasons. However, irrigation after depletion of $85 \%$ available soil water recorded the highest water use efficiency $\left(0.835\right.$ and $\left.0.706 \mathrm{Kg} / \mathrm{m}^{3}\right)$, followed by irrigation after depletion of $70 \%$ available soil water $\left(0.779\right.$ and $\left.0.655 \mathrm{Kg} / \mathrm{m}^{3}\right)$, as compared to irrigation after depletion of $40 \%$ available soil water which recorded the lowest mean value of water use efficiency $\left(0.492\right.$ and $\left.0.414 \mathrm{Kg} / \mathrm{m}^{3}\right)$, during both seasons.

Where water is the limiting factor to crop production, deficit irrigation can enhance WUE, so that the available water is better allocated. Water use efficiency (WUE) calculated as the harvested yield (kg) per volume of irrigation water $\left(\mathrm{m}^{3}\right)$ according to FAO recommendations (Doorenbos and Kassam, 1979). Out of several biotic and abiotic factors responsible, optimum water management is one of the most important factors that significantly influence productivity as well as the quality of the production (Bhriguvanshi et al., 2012).

In another side, increasing potassium silicate concentration increased water use efficiency (WUE), during 2017 and 2018 seasons. However, potassium silicate at $1500 \mathrm{mg} / \mathrm{l}$ silicate gave the highest mean values of water use efficiency $\left(0.782\right.$ and $\left.0.688 \mathrm{~kg} / \mathrm{m}^{3}\right)$, as compared to control treatment which recorded the lowest mean values of water use efficiency $(0.637$ and $0.501 \mathrm{~kg} / \mathrm{m}^{3}$ ), during both seasons, respectively.

WUE under water stress may be due to the vital role of K-silicate in reducing water-deficit stress on plant growth and yield (Gomaa et al. 2021b).

The interaction between irrigation treatments and potassium silicate concentration was highly significant on water use efficiency during both seasons. WUE under irrigation after depletion of $85 \%$ available soil water and foliar spraying with K-silicate at 1500 $\mathrm{mg} / \mathrm{l}$ silicate gave the highest values followed by irrigation after depletion of $70 \%$ available soil water under the same foliar spray of K-silicate. 
Table (5). Effect of irrigation levels (A), potassium silicate and their interaction (A * B) on proline content, oil content and water use efficiency of peanut during 2017 and 2018 seasons

\begin{tabular}{|c|c|c|c|c|c|c|c|}
\hline \multirow{2}{*}{\multicolumn{2}{|c|}{ Treatments }} & \multicolumn{2}{|c|}{$\begin{array}{c}\text { Proline } \\
\text { (mg/g) }\end{array}$} & \multicolumn{2}{|c|}{$\begin{array}{l}\text { Oil } \\
(\%)\end{array}$} & \multicolumn{2}{|c|}{$\begin{array}{c}\text { WUE } \\
\left(\mathbf{K g} / \mathbf{m}^{3}\right)\end{array}$} \\
\hline & & 2017 & 2018 & 2017 & 2018 & 2017 & 2018 \\
\hline \multicolumn{8}{|c|}{ A) Irrigation levels } \\
\hline \multicolumn{2}{|l|}{$85 \%$} & $236.08 \mathrm{a}$ & $219.55 \mathrm{a}$ & $34.36 \mathrm{~d}$ & $31.95 \mathrm{~d}$ & $0.835 \mathrm{a}$ & $0.706 \mathrm{a}$ \\
\hline \multicolumn{2}{|l|}{$70 \%$} & $224.42 b$ & $208.71 b$ & $36.95 \mathrm{c}$ & $34.36 \mathrm{c}$ & $0.779 b$ & $0.655 b$ \\
\hline \multicolumn{2}{|l|}{$55 \%$} & $208.87 \mathrm{c}$ & $194.72 \mathrm{c}$ & $39.88 b$ & $37.08 \mathrm{~b}$ & $0.725 \mathrm{c}$ & $0.592 \mathrm{c}$ \\
\hline \multicolumn{2}{|l|}{$40 \%$} & $187.19 \mathrm{~d}$ & $174.09 \mathrm{~d}$ & $45.31 \mathrm{a}$ & $42.14 \mathrm{a}$ & $0.492 \mathrm{~d}$ & $0.414 \mathrm{~d}$ \\
\hline \multicolumn{2}{|l|}{$\mathbf{L S D}_{(0.05)}$} & 4.76 & 4.12 & 0.39 & 0.36 & 0.01 & 0.01 \\
\hline \multicolumn{8}{|c|}{ D) Potassium silicate } \\
\hline \multicolumn{2}{|c|}{ Control } & $249.22 \mathrm{a}$ & $231.77 \mathrm{a}$ & $33.17 \mathrm{~d}$ & $30.85 d$ & $0.637 \mathrm{~d}$ & $0.501 \mathrm{~d}$ \\
\hline \multicolumn{2}{|c|}{$500 \mathrm{mg} / 1$} & $224.30 b$ & $208.59 b$ & $36.86 \mathrm{c}$ & $34.28 \mathrm{c}$ & $0.681 \mathrm{c}$ & $0.557 \mathrm{c}$ \\
\hline \multicolumn{2}{|c|}{$1000 \mathrm{mg} / \mathrm{l}$} & $201.87 \mathrm{c}$ & $178.73 \mathrm{c}$ & $40.95 b$ & $38.09 \mathrm{~b}$ & $0.731 b$ & $0.619 b$ \\
\hline \multicolumn{2}{|c|}{$1500 \mathrm{mg} / \mathrm{l}$} & $181.18 \mathrm{~d}$ & $168.96 \mathrm{~d}$ & $45.51 \mathrm{a}$ & $42.32 \mathrm{a}$ & $0.782 \mathrm{a}$ & $0.688 \mathrm{a}$ \\
\hline \multicolumn{2}{|c|}{$\mathbf{L S D}_{(0.05)}$} & 0.75 & 0.22 & 0.07 & 0.06 & 0.003 & 0.001 \\
\hline \multicolumn{2}{|c|}{$\begin{array}{c}\text { The interaction } \\
(\mathbf{A} * \mathbf{B})\end{array}$} & $* *$ & $* *$ & $* *$ & $* *$ & $* *$ & $* *$ \\
\hline \multirow[t]{2}{*}{$\begin{array}{l}\text { Irrigation } \\
\text { Levels }\end{array}$} & $\begin{array}{c}\text { Potassium } \\
\text { silicate } \\
(\mathrm{mg} / \mathrm{l})\end{array}$ & & & & & & \\
\hline & Control & 274.59 & 202.49 & 29.13 & 27.09 & 0.440 & 0.351 \\
\hline \multirow[t]{3}{*}{$85 \%$} & 500 & 247.13 & 182.23 & 32.37 & 30.10 & 0.473 & 0.390 \\
\hline & 1000 & 222.42 & 164.01 & 35.97 & 33.45 & 0.509 & 0.433 \\
\hline & 1500 & 200.19 & 147.61 & 39.96 & 37.17 & 0.547 & 0.481 \\
\hline \multirow{4}{*}{$70 \%$} & Control & 261.03 & 226.48 & 31.33 & 29.13 & 0.670 & 0.502 \\
\hline & 500 & 234.92 & 203.83 & 34.81 & 32.37 & 0.706 & 0.557 \\
\hline & 1000 & 211.43 & 183.45 & 38.68 & 35.97 & 0.743 & 0.619 \\
\hline & 1500 & 190.29 & 165.10 & 42.97 & 39.96 & 0.782 & 0.688 \\
\hline \multirow{4}{*}{$55 \%$} & Control & 243.53 & 242.75 & 33.81 & 31.44 & 0.696 & 0.555 \\
\hline & 500 & 219.17 & 218.48 & 37.57 & 34.93 & 0.749 & 0.617 \\
\hline & 1000 & 197.26 & 196.63 & 41.74 & 38.82 & 0.805 & 0.686 \\
\hline & 1500 & 175.53 & 176.97 & 46.38 & 43.13 & 0.865 & 0.761 \\
\hline \multirow{4}{*}{$40 \%$} & Control & 217.73 & 255.37 & 38.42 & 35.73 & 0.742 & 0.598 \\
\hline & 500 & 195.95 & 229.83 & 42.69 & 39.70 & 0.798 & 0.665 \\
\hline & 1000 & 176.36 & 206.85 & 47.43 & 44.12 & 0.868 & 0.739 \\
\hline & 1500 & 158.72 & 186.16 & 52.71 & 49.02 & 0.933 & 0.821 \\
\hline $\mathbf{L S D}_{(0.05)}$ & & 0.87 & 0.25 & 0.08 & 0.07 & 0.004 & 2.39 \\
\hline
\end{tabular}

- $\quad$ Irrigation level: irrigation after depletion of $40 \%, 55 \%, 70 \%$ and $85 \%$ available soil water. Means followed by the same letter within each column are not significant different at 0.05 level of probability.

** Denotes significant at 0.01 level of probability.

\section{CONCLUSION}

The results can recommend that spraying the Giza 6 variety of peanut crop with potassium silicate at $1500 \mathrm{mg} / \mathrm{l}$ silicate four times as applied after $(35,45,55$ and 65 days from planting) to alleviate deleterious impacts of drought stress and irrigation after depletion of $55 \%$ available soil water to save water under water deficit conditions at South Tahrir El-Beheira Governorate as this combination has a significant effect and obtained high yield and its components under this study conditions and the similar conditions areas. 
REFERENCES

Abdalla, A.A., M.A. El-Howeity and A.H. Desoky (2009). Response of peanut crop cultivated in newly reclaimed soil to inoculation with plant growth-promoting Rhizobacteria. Minufiya J. Agric. Res., 34(6): 2281-2304.

Ahmad, A., M. Afzal, A.U.H. Ahmad and M. Tahir (2013). Foliar effect of silicon on yield and quality of rice. Cercetări Agronomiceîn Moldova, 3: 21-28.

Amir, Y., T. Benbelkacem, L. Hadni and A. Youyou (2005). Effect of irrigation and fertilization on characteristics of peanut seeds cultivated near Tizi-Ouzou. J. Agric. Food Chem., 4: 879-885.

Anjum, S. A., X. Xie, L. Wang, M. F. Saleem, C. Man and W. Lei (2011). Morphological, physiological and biochemical responses of plants to drought stress. Afri. J. Agric. Res., 6(9): 2026-2032.

Arruda, I.M., V. Moda-Cirino, J.S. Buratto and J.M. Ferreira (2015). Growth and yield of peanut cultivars and breeding lines under water deficit. ISSN 1983- 4063 www.agro.ufg.br/pat - Pesq. Agropec. Trop., Goiânia, 45(2): 146-154.

Asgharipour, M. R. and H. Mosapour (2016). A foliar application silicon enhances drought tolerance in Fennel. J. Animal \& Plant Sci., 26(4):1056-1062.

Ashraf, M. (2010). Inducing drought tolerance in plants. Biotech. Adv., 28: 169-183.

Balakhnina, T. and M. Borkowska (2013). Effects of silicon on plant resistance to

environmental stresses: review. Int. Agrophys., 27:225-232.

Bhriguvanshi, S.R., T. Adak, K. Kumar, V.K. Singh and A. Singh. (2012). Impact of fertigation regimes on yield and water use efficiency of mango (Mangifera indica L.) under subtropical condition. Ind. J. Soil Cons. 40(3): 252-256

CGIAR (2005). Groundnut (Arachis hypogaea L.). Consultative Group on Int Agric Research. http://www.cgiar.org/ impact/researchground nut.html.

Crusciol, C.A., A.L. Pulz, L.B. Lemos, R.P. Soratto and G.P. Lima (2009). Effects of silicon and drought stress on tuber yield and leaf biochemical characteristics in potato. Crop Sci., 49: 949-954.

Demiral, T. and I. Turkan (2005).Comparative lipid peroxidation, antioxidant defense systems and proline content in roots of two rice cultivars differing in salt tolerance. Environ.\&Exp. Bot., 53(3):247-257.

Doorenbos, J. and Kassam, A.H. (1979). Yield response to water. FAO Irrigation and Drainage, Paper 33, Rome, 193 p.
El-Naggar, M.E., N.R. Abdelsalam, M.M.Fouda, M.I.Mackled, M.A. Al-Jaddadi, H.M. Ali, M.H. Siddiqui and E.E.Kandil (2020). Soil application of nano silica on maize yield and its insecticidal activity against some stored insects after the postharvest. Nanomaterials, 10(4):739.

Epstein, E. (1999). Silicon. Annual Review of Plant Physiology Plant Molecular Biol., 50: 641664.

Farooq, M., A. Wahid, N. Kobayashi, D. Fujita and S.M.A. Basra (2009). Plant drought stress: effects, mechanisms and management. Agron. Sustain. Dev., 29:185-212.

Fienebaum. V., D.S. Santos and M.A. Tillmann (1991). Influence of water deficit on the yield components of three bean cultivars. Pesquisa-Agropecuaria Breasileria. 26(2): 275-280.

Girdthai, T., S. Jogloy, N. Vorasoot, C. Akkasaeng, S. Wongkaew, C.C. Holbrook and A. Patanothai (2010). Associations between physiological traits for drought tolerance and aflatoxin contamination in peanut genotypes under terminal drought. Plant Breed., 129:693-699.

Gomaa, M. A., E. E.,Kandil, A. Z. El-Dein, AM. E.Abou-Donia (2020). Effect of irrigation intervals and foliar application of potassium silicate on growth of maize. Egyptian Academic Journal of Biological Sciences, H. Botany, 11(1): 103-109.

Gomaa, M.A., E.E Kandil, A.A. El-Banna and D. H. Chelaby (2021a). Response of some maize hybrids to foliar application of silicon under soil affected by salinity. Egyptian Academic Journal of Biological Sciences, H. Botany, 12(1): 18.

Gomaa, M. A., E. E.,Kandil, A. Z. El-Dein, AM. E.Abou-Donia, H. M.Ali and N. R. Abdelsalam: (2021b). Increase maize productivity and water use efficiency through application of potassium silicate under water stress. Scientific reports, 11(1), 1-8.

Gomez and Gomez (1984). Statistical procedures in agricultural research. $2^{\text {nd }}$ edition. Wiley, NewYork

ICRISAT (2011). Groundnut (Arachis hypogaea L.). Hyderabad, India: International Crop Research Institute for the Semi-Arid Tropics. Prod. Adv. Agron., 77: 185-268.

Kambiranda, D.M., H.K.N. Vasanthaiah, R. Katam, A. Ananga, S.M. Basha and K. Naik (2012). Impact of drought stress on peanut (Arachis hypogaeaL.) productivity 
and food safety. In: Vasanthaiah HKN, Kambiranda DM, editors. Plants and Environment. Rijeka, Croatia: In Tech, pp. 249-272.

Kandil, E.E., A. A. Farag and M. I.A El-Shabory (2019). Effect of planting dates and silicon foliar application on soybean productivity. Advanced J. of Agric. Sci., 24(3):211-225.

Korte, L.L., J.H. Williams, T.E. Specht and R.C. Sorensen (1993). Irrigation of soybean genotypes during reproductive ontogeny. Agronomic responses. Crop Sci., 28: 521530.

Ma, J. F., K. Tamaki and M. Ichii (2001). Role of root airs and lateral roots in silicon uptake by rice. Plant Phy., 127: 1773- 1780.

Mauad, M., C. Crusciol, A. Nascente, H. Filho and G. Lima (2016). Effects of silicon and drought stress on biochemical characteristics of leaves of upland rice cultivars. Revista Ciência Agronômica, 47(3): 532-539.

Nageswara, R.R.C., S. Singh, M.V.K. Sivakumar, K.L. Srivastava and J.H. Williams (1988). Effect of water deficit at different growth phase of peanut. I Yield responses. Agron. J., 77: 782-786.

Nautiyal, P.C., V. Ravindra, A.L. Rathnakumar, B.C. Ajay and P.V. Zala (2002). Genetic variation in photosynthetic rate, pod yield and yield components in Spanish groundnut cultivars during three cropping seasons. Field Crop Res., 125:83-89.

Page, A.L., R.H. Miller and D.R. Keeney (1982). Methods of Chemical Analysis. Part 2: Chemical and Microbiological Properties $\left(2^{\text {nd }}\right.$ Ed.). American Society of Agronomy, U.S.A.

Pandey, R.K., W.A.T. Herrera, A.N. Villegas and J.W. Pendleton (1984). Drought response of grain legumes under irrigation gradient Plant growth. Agron. J., 76: 557-560.

Patil, H., R. V. Tank and M. Patel (2017). Significance of silicon in fruit crops- A Review. Plant Archives., 17(2):769-774.

Pilon, C., R.P. Soratto, F. Broetto and A.M. Fernandes (2014). Foliar or soil applications of silicon alleviate waterdeficit stress of potato plants. Crop Ecology \& Phys., 106(6): 2325- 2334.

Prabawo, A., B. Prastawo and G.C. Wright (1990). Growth, yield and soil water extraction of irrigated and dryland peanuts in South Sulawesi. Indonesia. Irrig. Sci., 11:63-68.

Prakash, N. B., N. Chandrashekhar, C. Mahendra, S. U. Patil, G. N. Thippeshappa and H. M. Laane (2011). Effect of foliar spray of soluble silicic acid on growth and yield parameters of wet land rice in hilly and coastal zone soils of Karnataka, South India, J. Plant Nutr., 34 (12):1883-1893.
Ravindra, V., P.C. Nautiyal and Y.C. Joshi (1990). Physiological analysis of drought resistance and yield in groundnut (Arachis hypogaeaL). Trop. Agric. Trinidad, 67: 290-296.

Reddy, T.Y., V.R., Reddy and V. Anbumozhi (2003). Physiological responses of peanut (Arachis hypogaeaL.) to drought stress and its amelioration: a critical review. Plant Growth Regul., 41: 75-88.

Sapre, S.S. and D.N. Vakharia (2016). Role of silicon under water deficit stress in wheat: (Biochemical perspective): A review. Agric. Rev., 37(2): 109-116.

SAS (2002). By SAS institute INC., Cary, NC, USA. SAS (r) proprietary software version 9.00.

Seyed, A, A.R., M.H. Gharine, A.M. Bakhshande, Q.A. Fathi and A. Naderi (2011). Effects of final drought stress (the end of the growing season) on grain yield, yield components, oil content, protein and growth properties of rapeseed (brassica napus) in ahvaz weather conditions. plant production (farm scientific journal). 34(2): 53-66.

Shedeed, S. I. (2018). Assessing effect of potassium silicate consecutive application on forage maize plants (Zea mays L.). J. Inn. Pharm. \& Biol. Sci., 5 (2): 119-127.

Songsri, P., S. Jogloy, N. Vorasoot, C. Akkasaeng, A. Patanothai and C.C. Holbrook (2008). Root distribution of droughtresistant peanut genotypes in response to drought. J. Agron. Crop Sci., 194: 92-103.

Szabados, L. and A. Savoure (2010). Proline: a multifunctional amino acid. Trends in Plant Sci.,15: 89-97.

Toprope, V.N., V.G. Makne and N.P. Jangwad (2004). Identification of groundnut varieties showing tolerance to drought. In National symposia: Enhancing productivity of groundnut for sustaining food and nutritional security. Oct 11-13: 54-55.

Vorasoot, N., P. Songsri, C. Akkasaeng, S. Jogloy and A. Patanothi (2003). Effect of water strees on yield and agronomic characters of peanut (Arachis hypogaeaL.). SongklanakarinJ. Sci. Technol., 25: 283288. 


\section{الملخص العربي}

\section{استخدام سيليكات البوتاسيوم لتخفيف تأثير إجهاد الجفاف على الفول السوداني المنزرع في الأراضي الرملية}

محمود عبدالعزيز جمعة'، إبراهيم فتح الله رحاب'، عصام إسماعيل قنديل'، على محمد محمد على'، وليد بريك جابر عبدالحفيظ'

1- قسم الإنتاج النباتى -كلية الزراعة ساباباشا-جامعة الإسكندرية r- قسم خصوبة وميكروبيولجيا الأراضى- مركز بحوث الصحراء- القاهرة

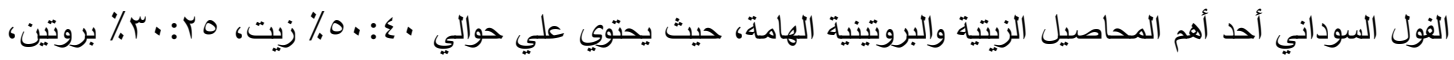

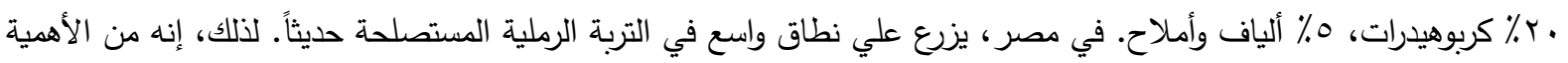

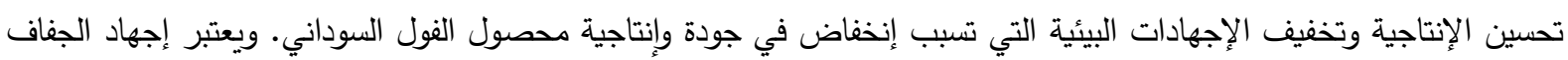
أحد أهم الإجهادات البيئية التي تقلل من إنتاجية ومحصول الفول السوداني المنزرع في الأراضي المستصلحة حديثاً بهصر .

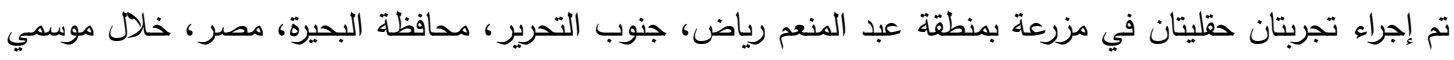

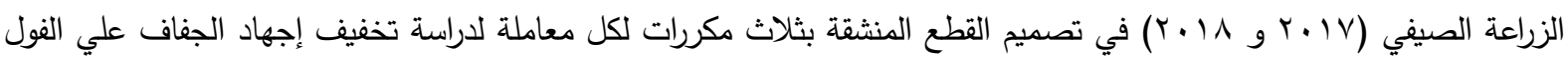

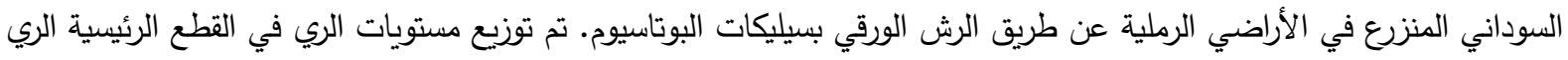

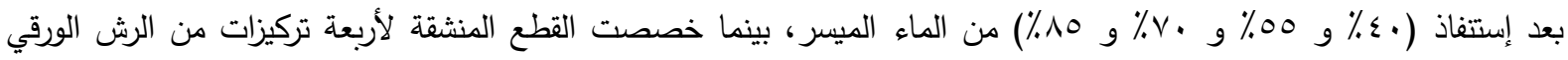

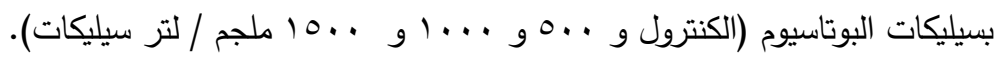

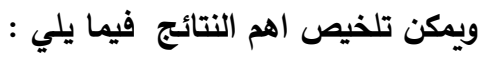

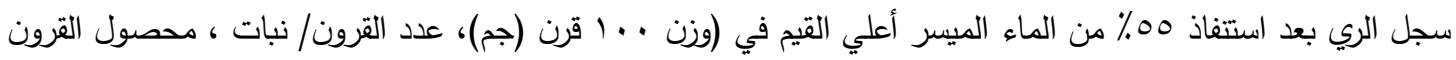

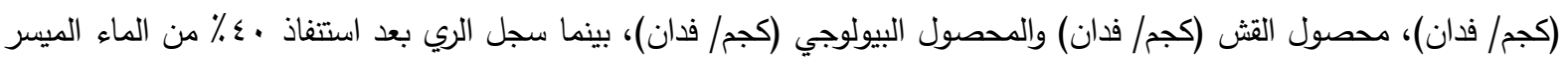

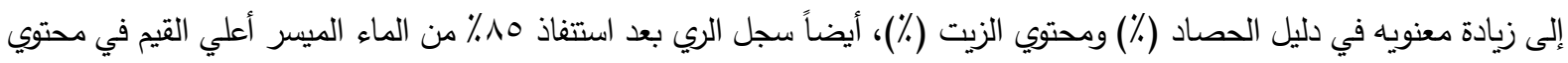
البرولين (مجم/ جم) و كفاءة إستخدام المياه (كجم/ مَّ) خلال الموسمين.

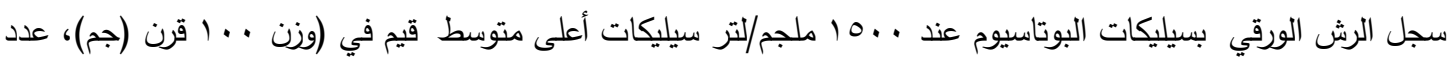

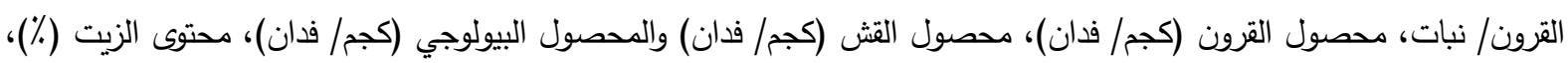

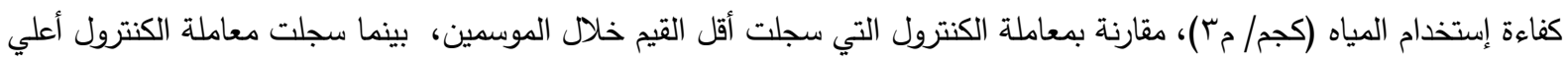

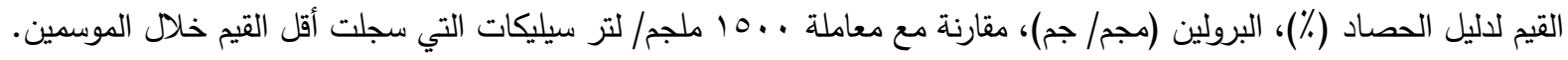

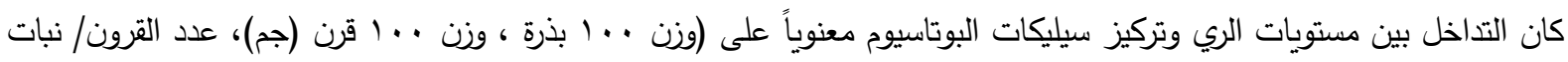

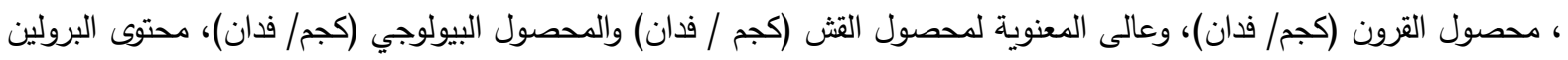

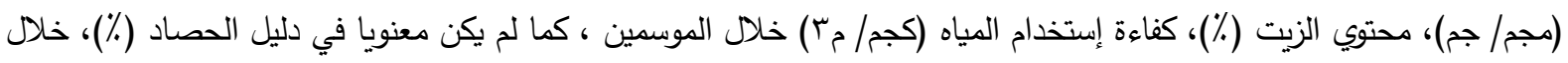

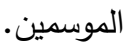
ختاماً، تشيرهذه الدراسة إلى أن سيليكات البوتاسيوم لها فاعلية في تخفيف الآثارالضارة للجفاف على محصول الفول السوداني المنزرع في الأراضي الرملية. التوصية:

يوصي البحث برش محصول الفول السوداني صنف جيزة 7 بسيليكات البوتاسيوم بتركيز . 10 ملجم/ لتز سيليكات أربع

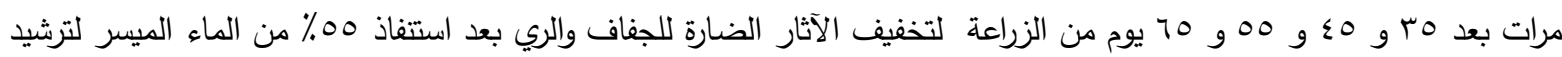

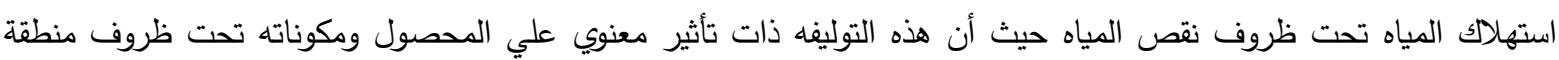

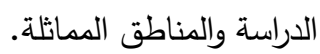

